MONTHLY REPORT NO. 10 - MAY 1967

\title{
COMPILATION OF CURRENT TECHNICAL EXPERIENCE AT ENRICO FERMI ATOMIC POWER PLANT
}

AEC CONTRACT NO. AT (11-1)-865 PROJECT AGREEMENT NO. 15

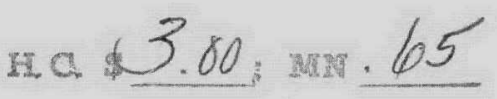

\begin{abstract}
SPONSOR: DIVISION OF REACTOR DEVELOPMENT AND TECHNOLOGY, UNITED STATES ATOMIC ENERGY COMMISSION
\end{abstract}

Prepared by

ATOMIC POWER DEVELOPMENT ASSOCIATES, INC. DETROIT, MICHIGAN

With the cooperation of POWER REACTOR DEVELOPMENT COMPANY And THE DETROIT EDISON COMPANY

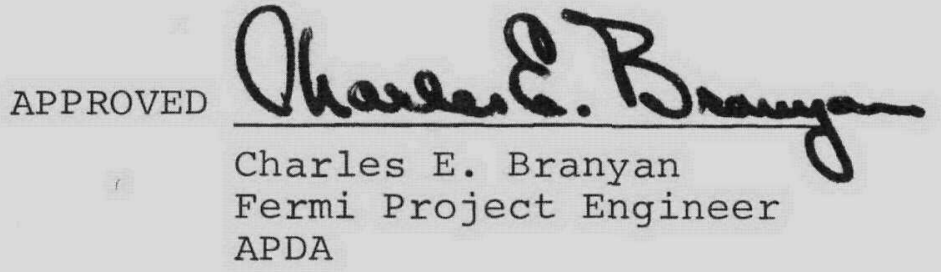

Author: J. F. McCarthy Commonwealth Associates Inc. Jackson, Michigan



Date Issued: July 1967 


\section{DISCLAIMER}

This report was prepared as an account of work sponsored by an agency of the United States Government. Neither the United States Government nor any agency Thereof, nor any of their employees, makes any warranty, express or implied, or assumes any legal liability or responsibility for the accuracy, completeness, or usefulness of any information, apparatus, product, or process disclosed, or represents that its use would not infringe privately owned rights. Reference herein to any specific commercial product, process, or service by trade name, trademark, manufacturer, or otherwise does not necessarily constitute or imply its endorsement, recommendation, or favoring by the United States Government or any agency thereof. The views and opinions of authors expressed herein do not necessarily state or reflect those of the United States Government or any agency thereof. 


\section{DISCLAIMER}

Portions of this document may be illegible in electronic image products. Images are produced from the best available original document. 


\section{REPORT NO. 10 - MAY 1967 \\ CONTENTS}

Section

Page

PREFACE

I

\section{CURRENT EXPERIENCE SUMMARY}

II

PLANT OPERATIONS
A. Reactor Unloading
B. Sodium and Gas Systems Performance
C. Shipment of Subassembly M140
D. Overflow Line Plugging

III

NEW EQUIPMENT

A. Shop Test of New Fuel Transfer Facility

B. Underwater Gaging Fixture

C. Exit Port Inspection Facility

A. Inspection of Subassembly M091

B. Review of Primary System Sodium Cleanup Methods

A. Removal of Plugs in the IHX Leakoff Gas Line

B. Secondary Sodium Pumps

C. No. I Steam Generator Tube-To-Tube Sheet Weld Repairs

D. Preparations for Sodium Drain Operation 
PREFACE

PURPOSE

The purpose of this monthly report is to make available to the fast reactor program the current experience being gained from the Enrico Fermi Atomic Power Plant.

SCOPE

The scope of this report includes all phases of current nuclear operating and maintenance experience at the Enrico Fermi Atomic Power Plant.

Earlier Fermi experience in certain selected areas is being recorded in a series of technical reports completed or in preparation by Atomic Power Development Associates, Inc. for the US Atomic Energy Commission under AEC Contract No. AT (11-1)-865, Project Agreement 15. This series of reports provides detailed information on the nuclear testing, rod drives, machinery dome, fuel subassemblies, fuel handling, reactor building ventilation, steam generators, pumps, flowmeters, level detectors, sodium sampling and development of the primary sodium system.

Items $A$ and $B$ in Section II are usually reported each month; items in the other sections are selected on the basis of their special significance during the month. Other items may be found in the monthly report submitted to the Atomic Energy Commission by Power Reactor Development Company in compliance with the requirements of Provisional Operating License No. DPR-9, as amended.

\section{BACKGROUND}

The Fermi reactor achieved initial criticality on August 23, 1963. An extensive series of nuclear tests was conducted at power levels below one megawatt thermal, through 1965. A high power (200 Mwt) license was issued on December 17, 1965, and operation in excess of 1 Mwt was initiated on December 29 , 1965. In January 1966, the power was raised in a series of steps to 20 Mwt. On April 1, 1966, power was first raised to 67 Mwt and on July 8, 1966, operation at 100 Mwt was initiated. On October 5, 1966, fuel damage occurred during an approach to power. Since this time the reactor has been shut down while the cause and extent of the damage are being investigated. 
It is assumed that those reading this report have a general familiarity with the plant. As an aid to the reader, a perspective drawing of the plant was included at the back of Report No. 1 .

Since this report is intended to follow closely the current proceedings at the Fermi plant, it must necessarily be treated as preliminary information, subject to supersedence in the light of subsequent experience. 


\section{SECTION I \\ CURRENT EXPERIENCE SUMMARY}

Subassembly M140 was sent to the Battelle Memorial Institute hot lab for destructive examination. The shipping pot gripper, which had seized during installation in the reactor vessel prior to loading Ml40, was repaired and performed satisfactorily during the transfer of Ml40 into the shipping cask.

Inspection of Subassembly M091 continued during May at Battelle. No abnormalities were noted except that one fuel pin was observed to be 0.2-inch longer than the others and the observation of sodium oxide and carbonate deposits in the spacer grids. These deposits are thought to be the result of the reaction of oxygen and other impurities in the cell atmosphere with sodium which was held between the spacer grids and fuel pins by surface tension. This reaction probably took place chiefly during the overnight period when the nitrogen atmosphere in the cell was lost. An additional dark powdery material containing almost 50 percent uranium was found in the spacer grids. This probably resulted from cutting into a fuel pin when the wrapper can was removed in the hot cell.

A review was made of the cleanliness of the primary system sodium and of the sodium cleanup methods currently in use and those used previously. It does not appear that sufficient impurities were dissolved in or carried by the sodium to have been the cause of the October 5, 1966, fuel failure.

As a result of the sodium cleanliness review, additional tests were made on the primary sodium plugging indicator by varying the NaK coolant temperature instead of the NaK flow and by decreasing the plugging orifice pressure drop. Sodium flow continued to stop suddenly when the sodium temperature reached $208 \mathrm{~F}$, indicating freezing rather than oxide precipitation. An additional test was conducted with the sodium temperature held between 210-240 F. The sodium flow was observed to gradually decrease to zero after 24 hours. Flow reappeared when the temperature was increased to $270 \mathrm{~F}$, indicating that the plugging temperature is between 210 and $270 \mathrm{~F}$.

The subassembly underwater gaging fixture was installed in the cut-up pool in the Fuel and Repair Building.

The new fuel transfer facility was shop tested at Atomics International and performance was in general very satisfactory with the exception of a few minor items which will require modification. 
A. Reactor Unloading

No further unloading of subassemblies from the reactor lattice (nor subassembly movements within the reactor) took place during May.

B. Sodium and Gas Systems Performance

1. Sodium Cold Traps and Plugging Indicators

May Operating Data.

$$
\begin{gathered}
\text { Cold Trap } \\
\text { Operation } \\
\text { (Hours) }
\end{gathered}
$$

Maximum Plugging

Temperature - F

Minimum Plugging

Temperature - F

* Sodium drained for steam generator tube sheet rewelding.

\section{Primary System Cover Gas Analysis}

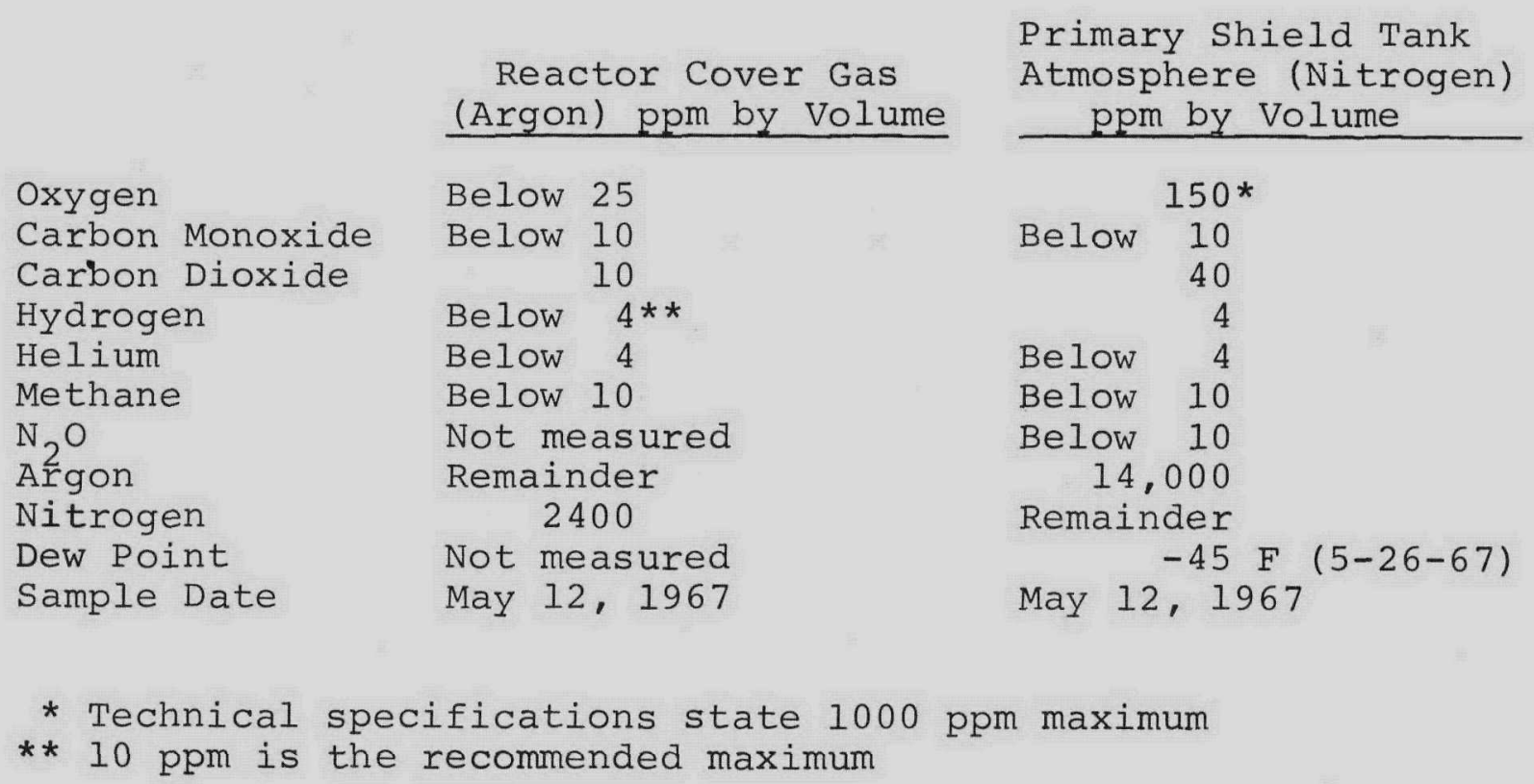

Primary

System

*

225

225

220

Loop 1 Loop 2 Loop 3

76
581 


\section{Primary System Gas Activity}

\begin{tabular}{c}
$\begin{array}{c}\text { Sample } \\
\text { Date }\end{array}$ \\
\hline
\end{tabular}

\begin{tabular}{|c|c|c|c|c|}
\hline & cation & $\mathrm{Da}$ & & (microcuri \\
\hline Reactor & Cover Gas & May & 12 & $8.3 \times 10^{-6}$ \\
\hline Reactor & Cover Gas & May & 26 & $4.7 \times 10^{-6}$ \\
\hline Primary & Shield Tank & May & 12 & $7.6 \times 10^{-7}$ \\
\hline Primary & Shield Tank & May & 26 & $6.6 \times 10^{-7}$ \\
\hline
\end{tabular}

4. Primary Sodium Chemical Analysis - April 1967

$\begin{array}{llll}\text { Oxygen } & 11,12,12 & \text { Iron } & 1.7,2.4 \\ \text { Carbon } & 19,22,27,40, & \text { Nickel } & 0.6,1.0 \\ & 43,46,72,205 & \text { Chromium } & \text { Below } 0.3, \\ & & & \text { Below } 0.4\end{array}$

*Hydroxide Hydrogen $1.1,1.2,1.6$

*Non-Hydroxide

$$
\text { Hydrogen } \quad 0.3,0.3,0.3
$$

* $1.3 \mathrm{ppm}$ recommended maximum for total hydrogen

Note: Values are in ppm by weight. One sodium sample coil was analyzed at several different points along its length to provide the separate readings indicated. 


\section{Shipment of Subassembly M140}

Subassembly M140 was sent to the Battelle Memorial Institute hot lab at Columbus, Ohio, via an escorted truck shipment on May 17th. A special shipping pot was placed in the reactor transfer rotor, the offset handling mechanism (manually operated) transferred Ml40 from the pot in which it had been residing to the special pot, the sodium-filled special pot was sealed and lifted into the shipping cask and the cask was sealed. The transfer was made at the exit port in the reactor building. The maximum radiation level at the surface of the cask was $0.22 \mathrm{mr} / \mathrm{hr}$.

The transfer method was the same as that used in April for subassembly M091 (Page 9 of Report No. 9) except that M091 was loaded at the Fuel and Repair Building and the special pot in which it was shipped was not sodium-filled.

The highest radiation level measured during the lifting of subassembly MI40 into the shipping cask was approximately $2 \mathrm{R} / \mathrm{hr}$ on the rear side of the cask at the joint between the cask and the support platform. A level of $15 \mathrm{R} / \mathrm{hr}$ was measured in April during the transfer of subassembly M091 utilizing the same geometry and radiation detector.

As reported on Page 12 of Report No. 9, the gripper for the special pot failed to disengage from the special pot when it was lowered into sodium at the reactor vessel exit port in April. Upon removal and disassembly of the gripper, it was concluded that there had been abnormally high sliding forces between the threaded stem of the gripper and the actuating nut. The stem was Inconel 600 hardened to 30 Rockwell C while the nut is Inconel $\mathrm{X}-750$ hardened to 65 Rockwell C. The threads are Acme threads. The threaded portion of the stem was replaced with stellite $6 \mathrm{~B}$ material. Cutting tool chatter marks were removed from the threaded portion of the nut by lapping. A special male thread piece was fabricated from carbon steel to provide a suitable lapping tool for the nut. The modified gripper performed without difficulty in the subsequent transfer and sealing of subassembly M140.

Inspection of subassembly Ml40 at Battelle has been postponed while a review is being conducted of the procedure to be used. Since it could be postulated that the oxide and carbonates observed in the grids of M09l at Battelle (see Page 18) had collected while M091 was in the reactor, a method to remove all the sodium prior to exposure of the subassembly to the hot cell atmosphere is desired. A study is under way of several solvents for sodium and sodium oxides and carbonates. If a suitable 
solvent is found, subassembly M140 may be solvent-cleaned immediately upon entering the hot cell. This procedure would prevent masking of any existing oxides and/or carbonates by reaction of the sodium with residual oxygen, water vapor or carbon dioxide in the hot cell.

\section{Overflow Line Plugging}

The 6-inch overflow line has become plugged several times since the october 5, 1966, shutdown. There had been few, if any previous plugs of the line. This 50-foot long line connects the upper portion of the reactor vessel with the overflow tank. The line penetrates the primary shield tank (PST) and the secondary shield wall. Insulation and electrical heating are provided on the line, and the line is sloped for drainage. The portion of the line inside the primary shield tank is shown on the reactor vessel elevation drawing on Page 22 of Report No. 6 .

All thermocouples on the line have indicated temperatures well above $208 \mathrm{~F}$, the freezing point of sodium. However, the electrical resistance heating on the line near the reactor vessel 6-inch overflow nozzle, and near the PST penetration is usually deenergized since continuous use of the heater produces undesirably high temperature differences between the nozzle and the adjacent reactor vessel wall.

The sodium level was raised slightly above the top of the overflow line and the heater near the nozzle was energized in cycles to raise the pipe temperature. The procedure was continued for 24 hours. The line was tested eight hours later and found to be clear.

The plug formed again within a short time when the heater was turned off and the sodium returned to its normal level.

On other occasions the line has been cleared without the aid of the resistance heater by merely raising the sodium level and waiting for the line to heat up by conduction. The line is tested once each week when the sodium level indicators are verified. Investigation of the plugging is continuing. 
A. Shop Test of New Fuel Transfer Facility

A shop test of the new fuel transfer facility at the Canoga Park, California plant of Atomic International was conducted in May. The test closely duplicated actual operating conditions.

In general performance was very satisfactory with the exception of a few minor items which require improvement.

The new fuel transfer facility will replace the existing cask car which has been in service for six years and which has required a large amount of maintenance, due in part to the complexity of its design. Both the new facility and the cask car use a specially designed car to carry a shielded fuel cask between the transfer port in the FARB and the exit port in the reactor building. The cars travel over the existing wide gage track.

The new facility makes use of several separate modules whereas the present cask car combines all the required functions into one large assembly. Other major differences are as follows:

\section{Present Cask Car}

1. Intended to transport 11 subassemblies or other reactor items

2. Power supplied by trolley-supported trailing cable

3. Subassembly decay heat removed by intermediate argon cooling recirculation system. Fresh subassemblies heated by the argon system.

4. Finned transfer pots supported by latch fingers at the top
New Facility

Transports only one item at a time

Self-contained battery power for propulsion and cooling.

Direct air cooling on outside of splined chamber. Heat transferred to or from chamber walls by close clearance with male splines on finned pot.

Finned pot supported on drip pan underneath the pot. 


\section{Present Cask Car $\quad$ New Facility}

5. One gripper support cable. Two gripper support tapes. One gripper actuation cable. One gripper actuation Cables layer-wound on drums tape. Tapes wound on reels, immersed portion does not reach reel.

In the case of the new fuel transfer facility, permanent bridge cranes will be mounted over the reactor exit port and over the FARB transfer port. Shielded floor valves will be positioned over the ports, a plug handling cask placed on the valve, the floor shield plug raised into the cask and the plug cask removed. The transport cask will then be placed on the floor valve and the gripper and hoist assembly mounted on top of the cask. A subassembly or another reactor component such as a control rod, neutron source or oscillator rod is then removed and/or inserted into the cask. The transfer car will carry the transport cask between the two buildings. See Page 12 for a sketch of the new facility and Pages 13 and 14 for photographs of the facility as installed and tested at Atomics International.

Delivery of the new facility is being postponed several months since the reactor is not in operation and the space at the reactor exit port is needed for the fuel inspection facility.

\section{B. Underwater Gaging Fixture}

The underwater gaging fixture was placed in the cut-up pool on May 15th. The Fuel and Repair Building overhead bridge crane lifted the bulky device in one piece, swung it into position and lowered it into the pool. The removable portions of the west wall and roof of the room over the cut-up pool were repositioned to permit the entrance of the gaging fixture. See Page 15 for photographs of the immersion operation.

The special fixture will be used for dimensionally checking the materials surveillance subassembly and other subassemblies. A further description of the fixture appears on Page 16 of Report No. 6. The fixture has been checked against the master gage and a dummy subassembly has been checked. Measurement of spacer pad size awaits completion of a special tool. At the end of May preoperational testing of the fixture was continuing. 


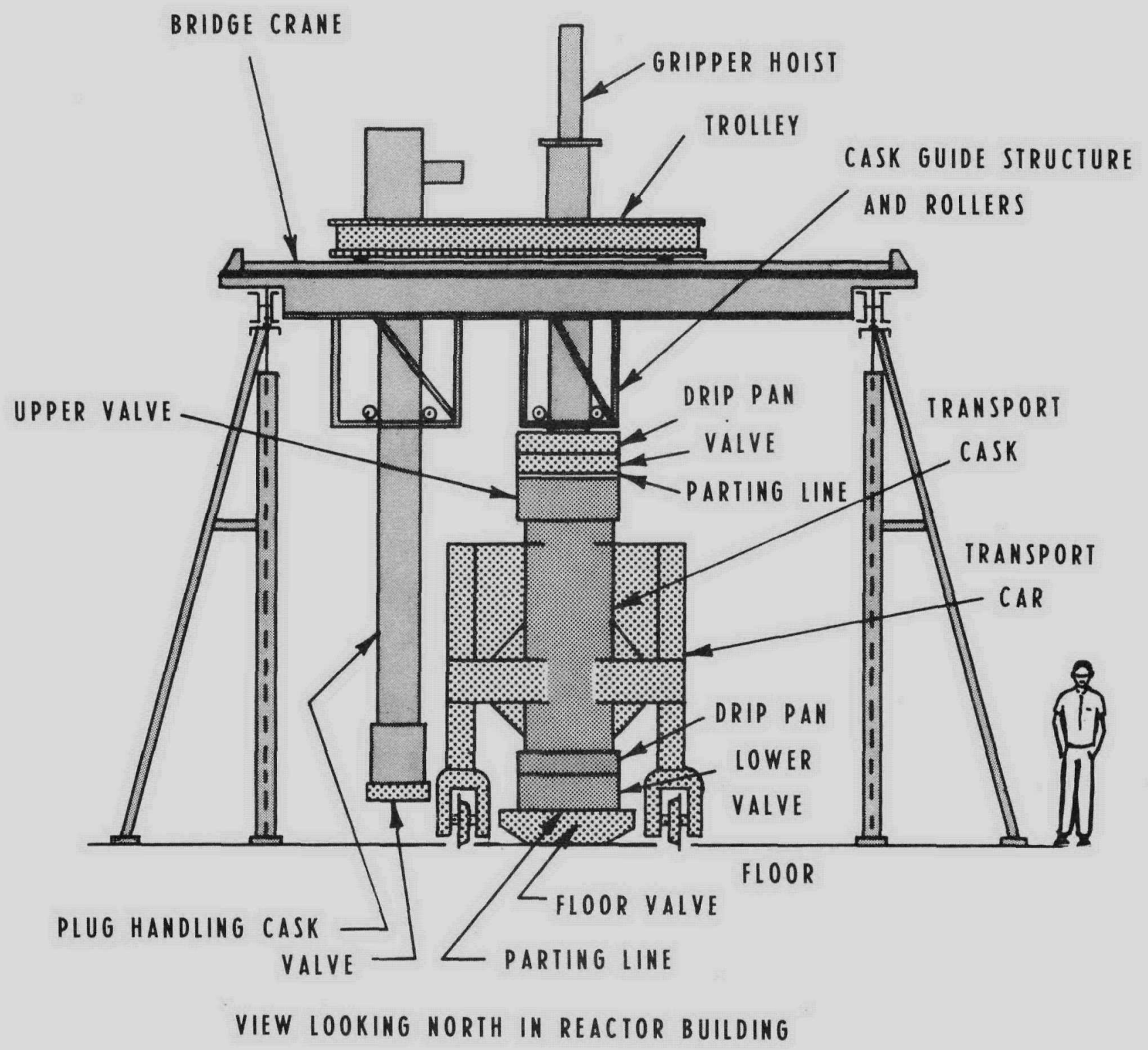

NOTE: THE FARB PLUG HANDLING CASK IS POSITIONED BY THE BLDG. CRANE, THEREFORE THE FARB BRIDGE CRANE DOES HOT MOVE LATERALLY

FUEL TRANSFER FACILITY 

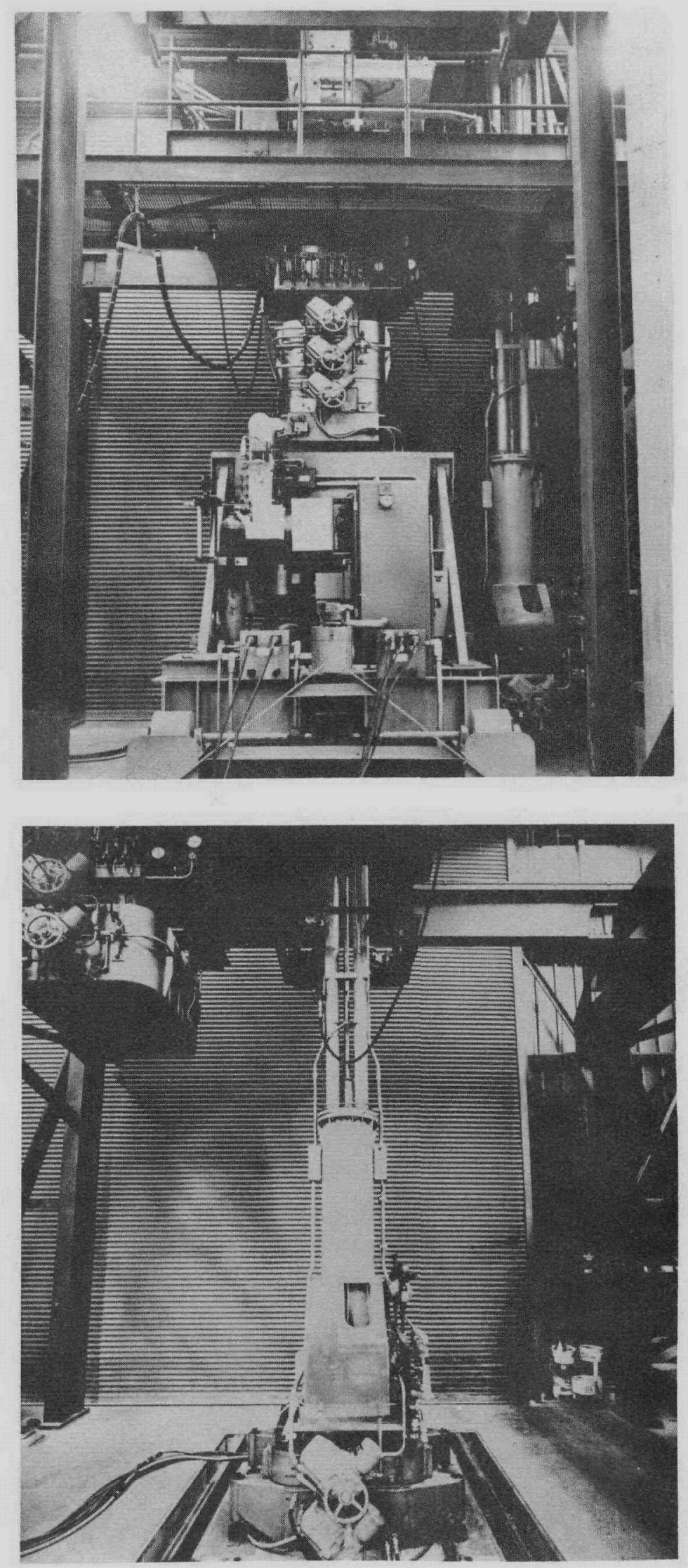

REAR VIEW OF TRANSPORT CAR AS WOULD APPEAR LOOKING SOUTH IN REACTOR BUILDING. PLUG CASK AT RIGHT.
REACTOR BUILDING PLUG REMOVAL CASK OVER SIMULATED EXIT PORT 


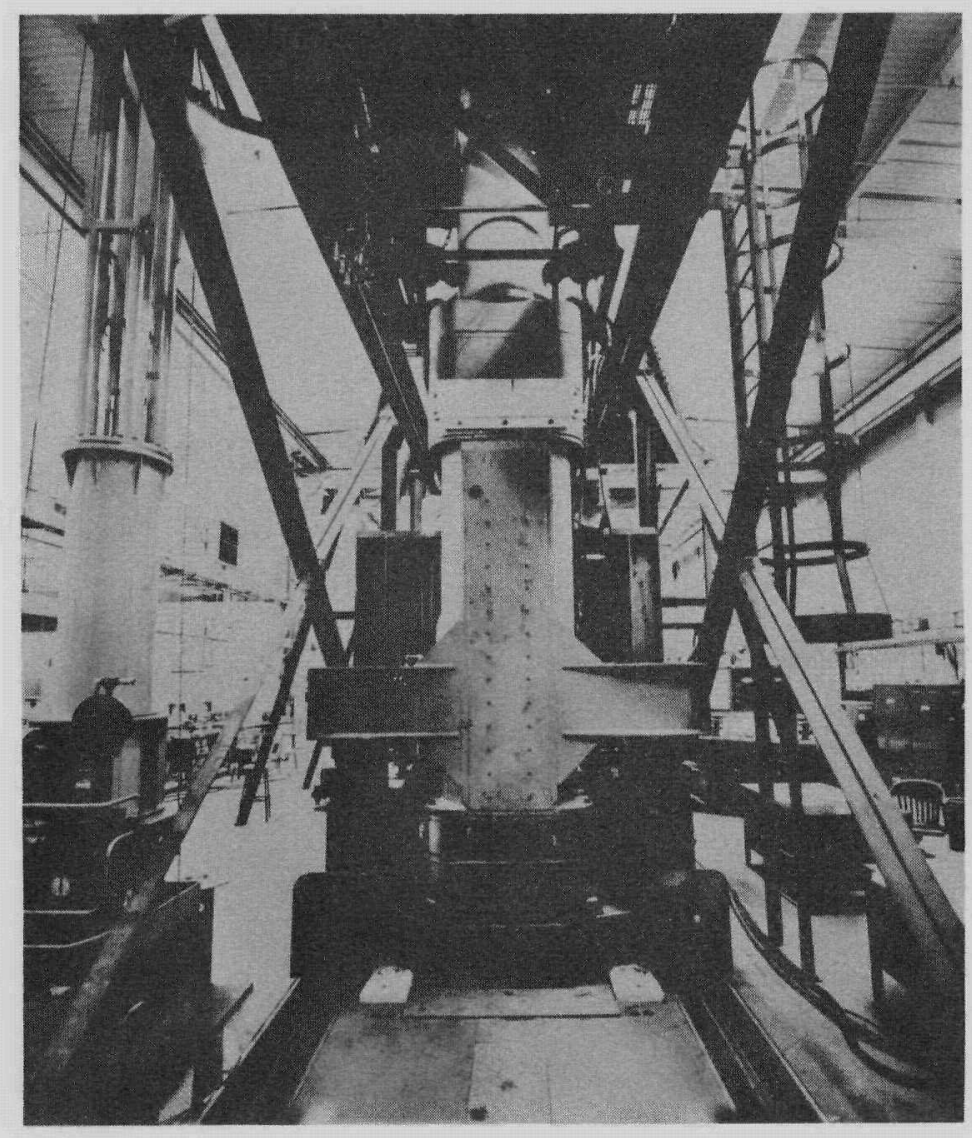

FRONT VIEW OF TRANSPORT CAR AND FARB BRIDGE CRANE WITH HOIST AND GRIPPER ASSEMBLY. PLUG CASK AT LEFT

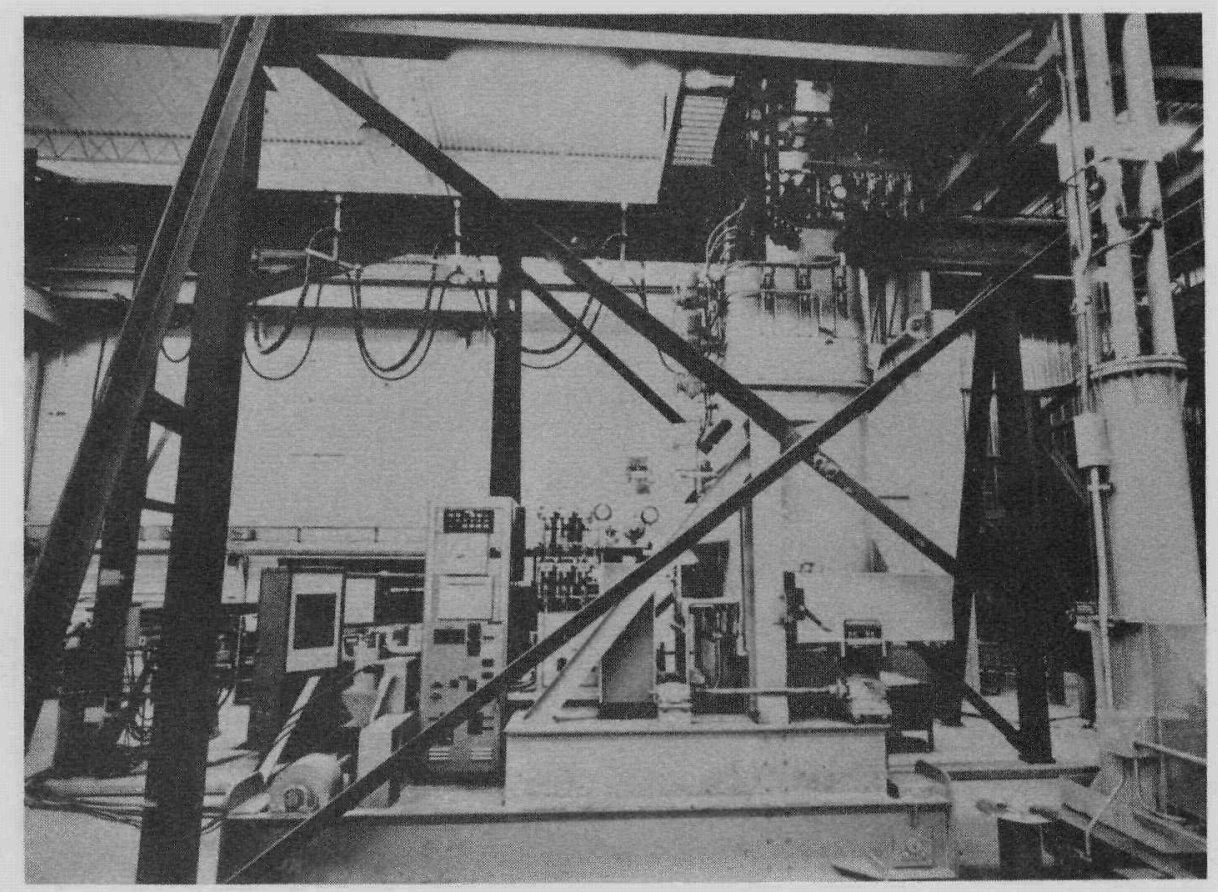

SIDE VIEW OF

IRANSPORT CAR AND FARB BRIDGE CRANE

SHOP TEST OF FARB FUEL TRANSFER FACILITY 


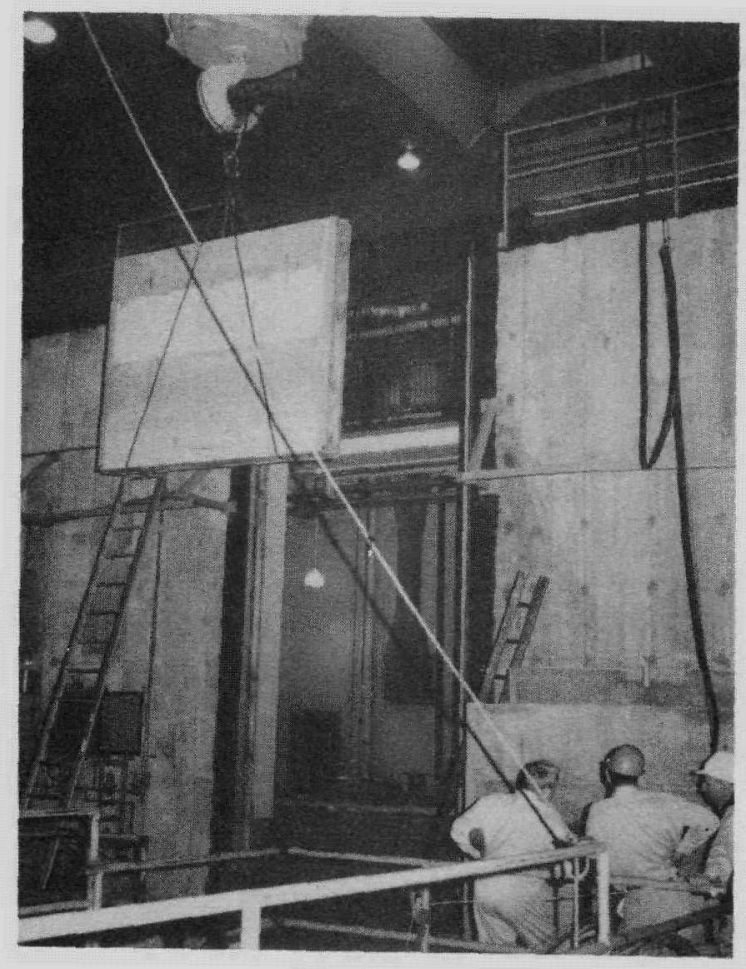

REMOVAL OF CUT-UP POOL ROOM WALL AND ROOF SECTIONS PERMITTED HANDLING GAGE IN ONE PIECE

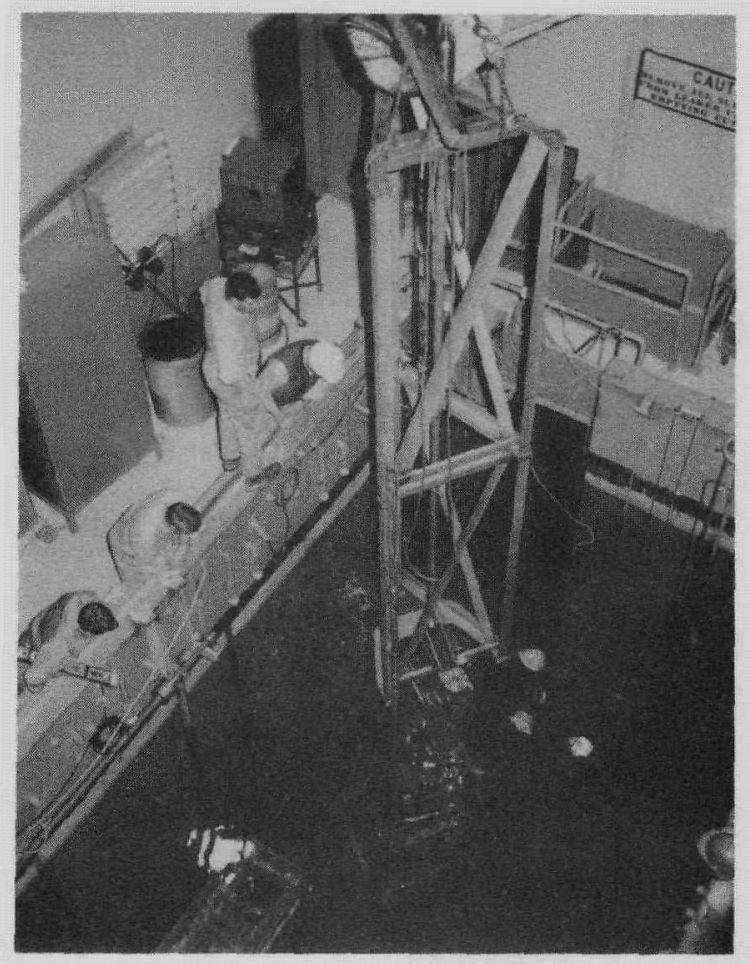

SUBASSEMBLY GAGE BEING LOWERED INTO THE CUT-UP POOL

INSTALLATION OF CUT-UP POOL SUBASSEMBLY GAGE 


\section{Exit Port Inspection Facility}

Assembly and testing of the exit port inspection facility continued during May. Loading of subassembly Ml40 into the shipping cask required temporary removal of the shield housing and inspection chamber. The facility support stand was also removed temporarily to eliminate an interference between the stand and the exit port flange which had previously been relieved by shimming the stand. The stand was replaced and was used to mount the exit port shield plug cask. After removal of the exit port shield plug, the chamber and housing were re-installed on the stand. Excessive leakage at the gripper latch rod (lower wrench) penetration was observed during leak tests. Design modifications will be made in this area. See Pages 25-27 of Report No. 5 for more information on the inspection facility.

\section{The viewing windows, lighting and valves have been} installed on the inspection chamber, and the shield windows have been installed in the shield housing. Preoperational testing of the subassembly hoist mechanism is continuing in the Fuel and Repair Building. Friction in the upper pulley bearing was sufficient to cause a 30-1b differential in the load sensing equipment. The sleeve bearing was replaced with a pair of ball bearings and the differential was reduced to about $1 / 21 \mathrm{~b}$.

The load sensing equipment utilizes a piezo-electric crystal to develop an electrical signal proportional to the force on the pulley. The force on the upper pulley equals twice the weight of the subassembly being lifted by the hoist mechanism into the inspection chamber. Loss of weight by a subassembly would most likely be indicative of loss of fuel due to melting and ejection. Core subassemblies weigh 121 pounds. 


\section{A. Inspection of Subassembly M091}

The inspection of subassembly M091 at the Battelle Memorial Institute hot lab in Columbus, Ohio, continued during the month of May. See Page 9 of Report No. 9 for previous information on this inspection. Measurements taken in the hot cell by optical means indicated that the subassembly wrapper can was not bowed. Dimensional measurements of the pads and wrapper can at the core location indicated no dimensional changes within the accuracy of the measurement method.

Gross gamma activity measurements of the subassembly were taken with the radiation detector at the core mid-plane and at various distances from the subassembly, with the following results: Distance from Subassembly,
inches

6

12

18

24

30

36
Radiation Level
$\mathrm{R} / \mathrm{hr}$

450

220

145

100

75

58

The inlet strainer was removed and appeared quite clean except for a thin film of sodium and oxide which covered some of the holes. The upper and lower axial blanket sections were cut off and internally inspected by means of a borescope. There were no signs of blanket rod damage or flow blockage. The thermocouple flow hole in the handling head was clear.

One pin in the fuel bundle was observed to be longer than the other pins by approximately 0.2 -inch. This pin is being removed for further examination. A high intensity light was placed at one end of the core section. It was observed that only one or two axial channels existed through the fuel bundle at the spaces between the pins and the grids. A 20-mil shim was inserted transversely between the fuel pins between each grid without encountering any obstructions. A photo of an identical fuel bundle is shown on Page 27 of Report No. 6 . 
The above-mentioned tests with the light and the free passage of the 20-mil shim indicated that material was present predominately in the grids around the fuel pins. This material, sodium oxides and/or carbonates, might have lodged in the grids during operation but more likely was formed in the subassembly in the hot cell due to the lack of a pure nitrogen atmosphere. The first night that M091 was in the hot cell, the cell atmosphere reached 18 percent oxygen because the liquid nitrogen supplier filled the wrong supply tanks.

A dunk test was conducted with a test grid and fuel pins to determine if liquid sodium would cling in the corners of the grid due to surface tension. The test confirmed that hangup occurs. It has therefore, been tentatively concluded that the material in the grids is most likely sodium oxide and/or carbonate formed by the action of the oxygen, water vapor or carbon dioxide in the cell (or the shipping cask) on the sodium retained in the grids. Further investigations of sodium purity (see Page 19) appear to confirm earlier opinions that the primary system sodium is not contaminated with oxide, carbonates or other impurities either in solution or present as particulates.

However, in addition to the oxides and/or carbonates present in the grids, a dark powdery material was noted in places when portions of the outer grid straps were removed and when several edge pins were removed. The material analyzes approximately as follows:

Material

Uranium

Molybdenum

Zirconium

Iron

Chromium

Nickel

Copper

Manganese

Silicon

Titanium

Aluminum

Potassium

Phosphorous
Percent by Weight

47
7
15
20
5
5
3
Trace
Trace
Trace
Trace
Trace
Trace

The values were obtained by an x-ray fluorescence analysis. The material averaged 5-10 mils in size, with a maximum particle size of 40 mils. This material probably resulted from cutting into a fuel pin when the fuel bundle wrapper can was cut and removed in the hot cell. 
B. Review of Primary System Sodium Cleanup Methods

\section{General}

A detailed review of past and present sodium cleanup methods was concluded in May. The possibility that the October 5, 1966, partial fuel meltdown could have been caused by a sodium coolant restriction in a fuel subassembly brought into question the past and current cleanliness of the primary sodium system. The review covered filtering, hot trapping, cold trapping, sample analyses and plugging temperature readings. Comparison was made with sodium cleanup experiences at other facilities. It does not appear that sufficient impurities were dissolved in or carried by the sodium to have been the cause of the October 5, 1966, fuel failure. The following paragraphs summarize the points covered in the review.

\section{Filtering}

The primary sodium was filtered as it was unloaded from the tank cars, using a 37 micron ( 1.5 mil) strainer screen with $250 \mathrm{sq}$ in. area. The filter plugged during the operation and was removed from the line. A second filter, also 37 micron, on the service system EM pump suction subsequently plugged and was also removed.

The sodium was transferred from the storage tanks to the primary system in November 1960. Dummy subassemblies with fine and coarse strainer screens (2-1/2 and $10-\mathrm{mil}$ openings) were installed in the reactor to clean up the sodium.

In May 1961 the sodium temperature was raised to $1000 \mathrm{~F}$. Off-gassing of the graphite in the rotating shield plug resulted in contamination of the sodium. Carbonaceous material was found to be the principal contaminant. A 1200 sq in. filter was installed in the primary sodium service system at this time. Strainer screen elements with 150, 37 and 5-micron openings were successively installed in the filter housing. The 5-micron element became damaged and permitted a bypass flow path.

The reactor vessel was drained in June 1962 for repairs to the hold-down mechanism and to the support plates. Several cubic feet of carbonaceous material were scraped from the walls of the vessel in the vicinity of the sodium gas interface near the bottom of the rotating shield plug. The vessel was refilled in December 1962 and initial criticality took place in August 1963. 
The last filter subassembly was removed from the reactor in December 1965. Filter subassemblies had been installed in all core positions and all except eight inner radial blanket positions. The filters picked up very little residue after mid-1963. In all, some 150 filter subassemblies were used to clean up the primary sodium but with a maximum of only 120 in use at any one time.

Fifty filter subassemblies were analyzed to determine how much residue they had retained. A total of 550 grams of residue were retained by the fifty subassemblies. The fine filter subassemblies caught approximately 75 percent of this total. Between 70 and 90 percent of the particles were smaller than $30 \mathrm{mils}$. The total amount of residue per subassembly ranged from 0.2 to 32 grams. The residue resembled lampblack and the average analysis indicated it was approximately 20 percent carbon, 50 percent sodium oxide, 15 percent iron oxide and the balance oxides of other metals and silicon oxide. Many of the filters were found to be plugged with this material.

The primary sodium was circulated for 57 hours through a cyclone separator in August 1962 at a flow rate of $2.5 \mathrm{gpm}$. only 0.5 gram of material was removed. The material was black and powdery and analyzed 51 percent carbon.

\section{Hot Trapping}

A temporary hot trap was operated for 300 hours at $1200 \mathrm{~F}$ in 1962. Less than 100 grams of carbon were removed from the sodium by carburization of the $1830 \mathrm{sq}$ ft of stainless steel foil. A permanent hot trap was installed and seven carbon removal runs have been made but there has been no detectable carbon pickup.

\section{Cold Trapping}

The original primary system cold trap was in service from 1960 to 1963, logging 3700 hours of operation at $50 \mathrm{gpm}$ sodium flow rate. The cold trap had a calculated maximum capacity of 290 lb of oxygen ( 1050 lb of sodium oxide) but post examination showed that only 50 lb of oxygen had collected in the mesh section of the original Fermi cold trap. The oxide collected in the bottom 12-inches of the 56-inch tall mesh section of the cold trap, completely blocking the normal flow path.

The replacement cold trap has operated less than 1000 hours. Approximately 700 hours of operation have been logged since the reactor fuel damage on October 5, 1966. There has been no significant increase in the cold trap radiation level due to fission product pickup. 
Both the original and present primary sodium cold traps cool the sodium by means of a NaK jacket on the cold trap to precipitate the oxides. The sodium then enters a low velocity region packed with stainless steel York mesh on which the oxides collect. A sketch of the cold trap is shown on Page 22.

\section{Sample Analyses}

Samples of the primary sodium are taken at least once a month and chemically analyzed. The results are reported each month in section II B of this report. The curve sheet on Page 14 of Report No. 7 displays the variation of several impurities (carbon, oxygen, hydrogen and iron) in the primary sodium during the period from May 1965 through August 1966.

Samples of the primary sodium have been taken in recent. months and analyzed for particulates, as reported on Pages 22, 18 and 25 of Report Nos. 5, 8 and 9, respectively.

The nature and extent of the chemical and physical impurities are comparable to those reported at other sodium installations. Analysis of a sample of fresh reactor grade sodium showed the amount of particulate matter to be comparable to that found in the present Fermi sodium.

\section{Plugging Indicator}

a. General

The primary sodium plugging indicator is cooled by means of a counter-flow NaK jacket. The orifice plate is perforated with 30-mil diameter holes. Sodium flow is held constant at approximately $0.6 \mathrm{gpm}$ and the pressure drop across the orifice plate is approximately $50 \mathrm{psi}$. The NaK is circulated at a constant inlet temperature of 160-180 F to cool the sodium. The NaK flow rate is increased until the sodium flowmeter indicates a flow blockage caused by cooling the sodium to its oxide precipitation temperature. The oxide crystals cause the flow blockage by lodging in the holes in the orifice plate. The sodium flow and temperature are noted on recording instrument charts. An electric heating element at the orifice raises the sodium temperature to re-dissolve the sodium oxide. operation of the plugging cycle is automatically controlled.

Recent plugging cycles have indicated flow blockage at a sodium temperature of $208 \mathrm{~F}$ (corrected for instrument calibration). This blockage is probably due to crystals of frozen sodium rather than oxide crystals. Sodium freezes at 208 F. Several different operating modes were employed with the primary system plugging indicator during May to determine if the mode of operation affected the plugging temperature. The procedures and results are given in the following paragraphs. 


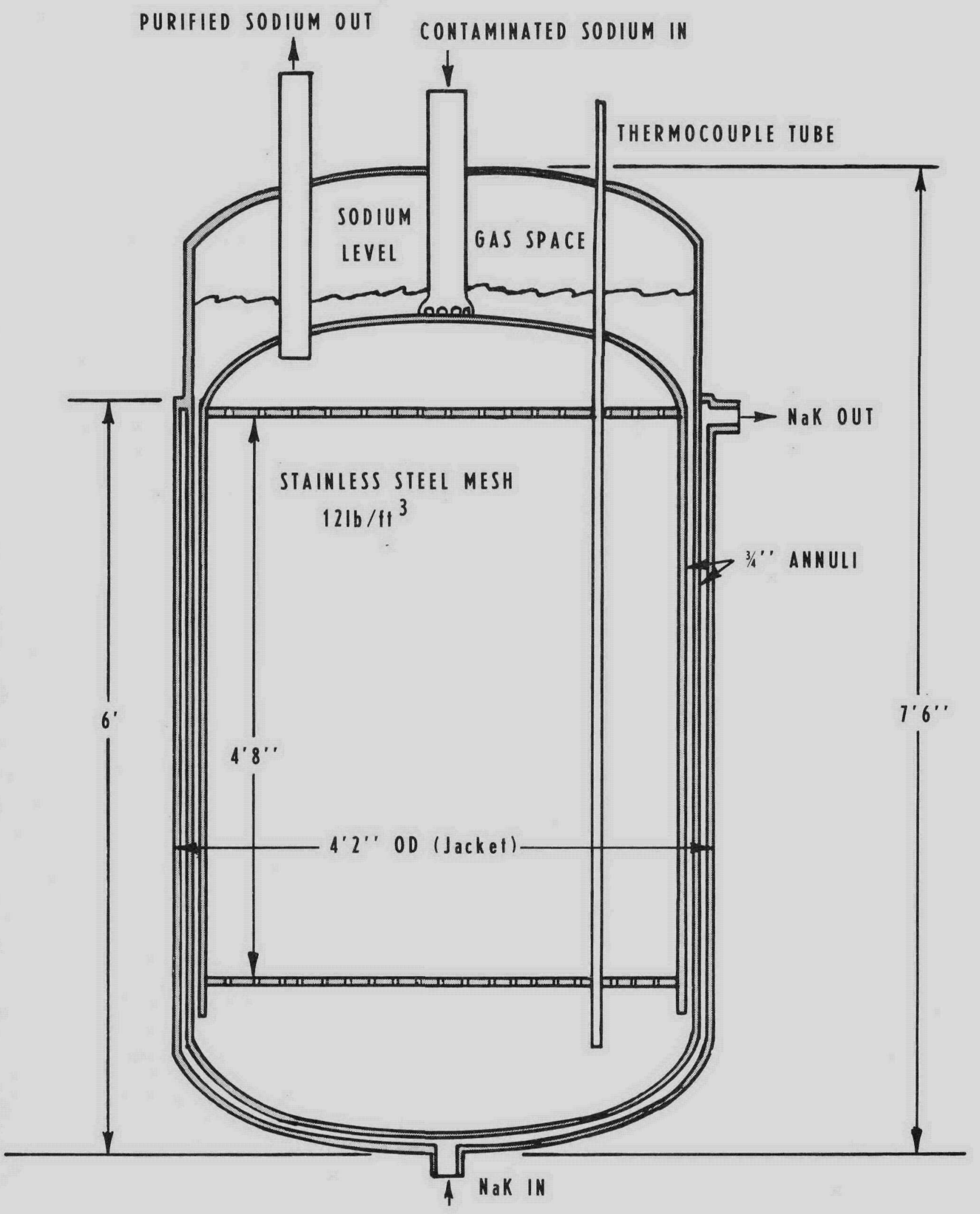

PRIMARY COLD IRAP 


\section{b. Constant NaK Flow and Decreasing NaK Temperature}

The NaK flow was held constant at $1.2 \mathrm{gpm}$ and the sodium flow was $0.6 \mathrm{gpm}$. The $\mathrm{NaK}$ temperature entering the plugging indicator was decreased at an average rate of 2-degrees per minute from about $400 \mathrm{~F}$ to $180 \mathrm{~F}$ over a 90-minute period. The sodium temperature decreased from $430 \mathrm{~F}$ to $208 \mathrm{~F}$ in the same period and the sodium flow stopped suddenly when the temperature reached $208 \mathrm{~F}$, indicating freezing.

\section{c. Decreased Plugging Orifice Pressure Drop With Conventional NaK Flow-Temperature Mode}

The overflow pump speed and sodium service system valving were adjusted so that the pressure drop across the plugging orifice was greatly reduced from its usual value of $50 \mathrm{psi}$. Sodium flow through the orifice was $0.6 \mathrm{gpm}$. This arrangement also resulted in very little increase in pressure drop at the orifice when it became plugged.

The NaK temperature into the plugging indicator was held at about $160-180 \mathrm{~F}$ and the NaK flow was increased automatically (the usual mode of operation). The sodium flow suddenly stopped when the temperature reached $208 \mathrm{~F}$, indicating freezing. A portion of the recorder chart, showing two plugging cycles made under these conditions, is shown on Page 25 .

\section{d. Combination of $\mathrm{b}$ and $\mathrm{c}$ Operating Modes}

NaK flow was held constant at $1.2 \mathrm{gpm}$, sodium flow was $0.6 \mathrm{gpm}$ with minimum pressure drop across the orifice. The $\mathrm{NaK}$ temperature was slowly decreased, causing the sodium temperature to decrease from $400 \mathrm{~F}$ to $208 \mathrm{~F}$ in three hours. The sodium flow suddenly stopped when the temperature reached $208 \mathrm{~F}$, indicating freezing.

\section{e. Constant Sodium Temperature}

The NaK flow was held constant throughout the run at $1.2 \mathrm{gpm}$. At the start of the run the sodium flow was $0.3 \mathrm{gpm}$, the sodium and $\mathrm{NaK}$ temperatures were both $430 \mathrm{~F}$, and there was minimum pressure drop across the plugging orifice. The NaK temperature was decreased slowly causing the sodium temperature to decline to $210 \mathrm{~F}$. With no other system adjustment having been made, the sodium flow had decreased to $0.23 \mathrm{gpm}$. The decrease may be due to the higher sodium viscosity at $210 \mathrm{~F}$ compared to the viscosity at $430 \mathrm{~F}$. This effect had been observed on other plugging runs. 
The sodium temperature was held relatively constant over the next 24-hour period. Acturally, it rose slowly to $240 \mathrm{~F}$ and then returned to $215 \mathrm{~F}$. The sodium flow slowly declined during the period and reached zero after 24 hours. The NaK temperature rose to $225 \mathrm{~F}$ and declined to $210 \mathrm{~F}$ during the 24-hour period. It was concluded that the sodium oxide saturation or plugging temperature was between $210 \mathrm{~F}$ and $250 \mathrm{~F}$. See Page 26 for a graph showing the sodium flow and temperature during the run. 


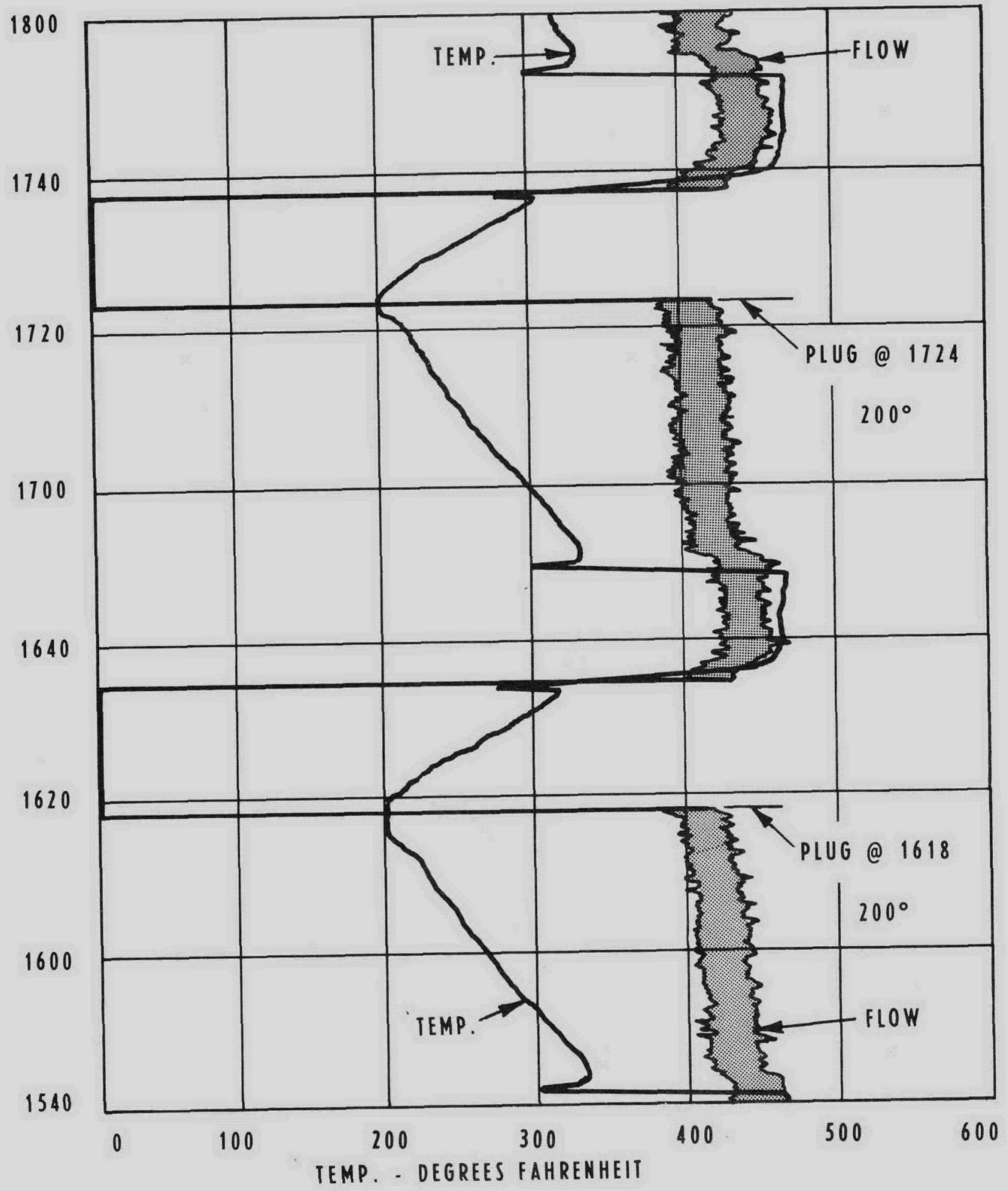

0

$0.3 \quad 0.6$

0.9

FLOW - GALLONS PER MINUTE

PIUGGING INDICATOR RECORDER CHART 


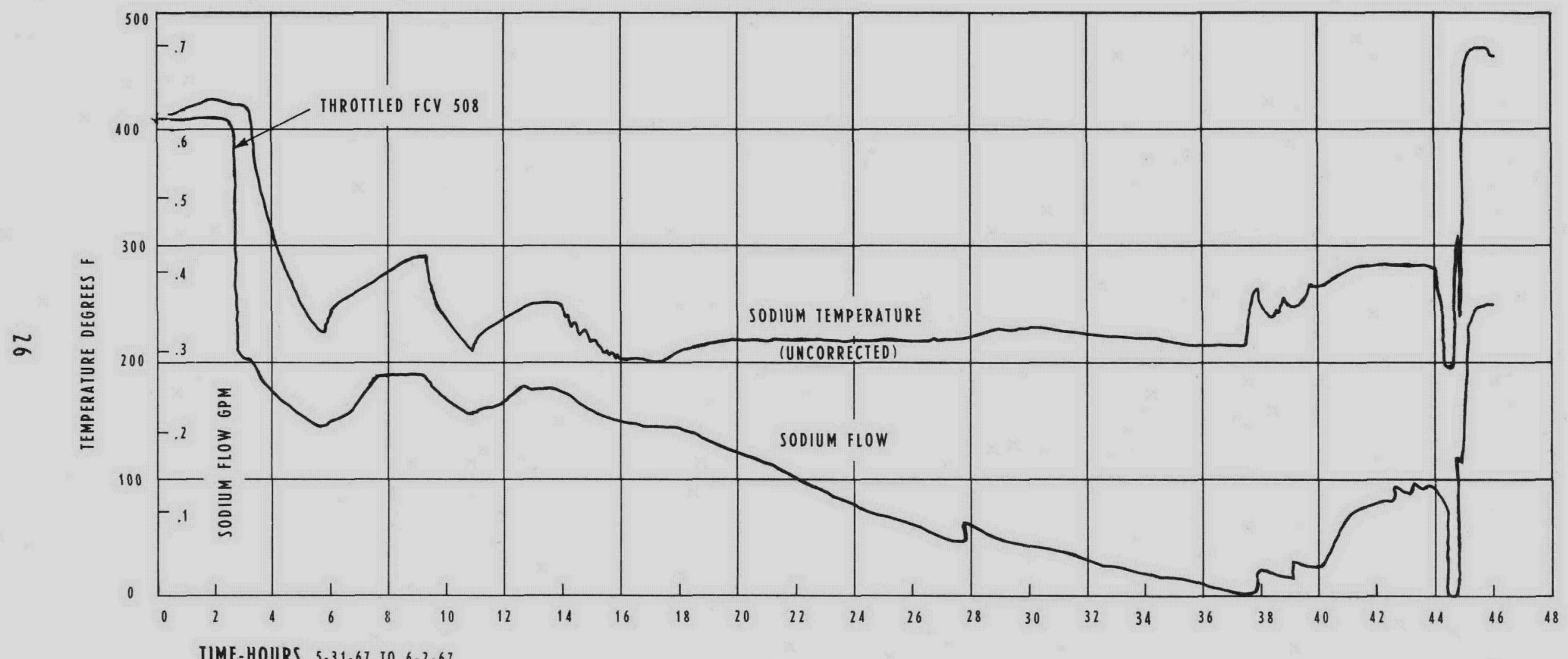

RESULTS OF PRIMARY SODIUM PLUGGING INDICATOR RUN 


\section{SECTION V}

\section{MAINTENANCE}

\section{A. Removal of Plugs in the IHX Leakoff Gas Line}

A flexible metallic seal in the intermediate heat exchanger (IHX) separates the primary system sodium from the higher pressure secondary sodium. Leakage past the seal is collected in a 10-gallon leakoff tank adjoining each IHX. The tanks are drained by gravity to the No. 3 secondary sodium storage tank in the basement of the steam generator building. Leakoff tank level is checked by level probes installed in standpipes near the storage tank, and the tanks are drained by periodic opening of hand valves in the leakoff lines near the storage tank.

A gas equalizing line connects the tops of the standpipes with the tops of the leakoff tanks. An 85-foot portion of this line is $1 / 2-i n c h$ pipe. It recently was determined that the 1/2-inch line, which is heated, had become plugged due to a sodium spill-over from the standpipes. Further investigation showed that the line was plugged at three different locations. Almost the entire length of $1 / 2$-inch pipe was probably filled with sodium. Approximately one gallon of sodium was collected from the line when gas was blown through it after the blockages were cleared.

The nature of the blockages were as follows:

1. Frozen sodium at an elbow in the line which was inadequately heated and insulated. This section of the $1 / 2-i n c h$ gas equalizing line is insulated and induction-heated in common with one of the 3 -inch leakoff tank drain lines. The heating and insulation deficiences were corrected.

2. Insufficient heat in a section of the line heated with resistance heating elements. A spare element in the same location was energized to increase the temperature of the line to melt the sodium which had collected at this section.

3. A collection of sodium oxide in and adjacent to a bellows sealed block valve in the gas line. Cause of the oxide formation has not been definitely established. The section of pipe containing this valve was replaced. Before discovery of the oxide, it was thought that the valve might have been stuck shut. The valve design relies on a return spring to lift the disc from the seat and, even with the bonnet removed, there is no convenient method of determining whether the valve is open or -closed. 
From this experience, together with the past plugging problems on 1/2-inch lines seeing sodium or sodium vapor, it has been concluded that lines considerably larger than $1 / 2$-inch should be installed wherever possible.

\section{B. Secondary Sodium Pumps}

The upper motor bearings on the No. 3 secondary sodium pumps were replaced in May. There are two ball bearings side-by-side at the upper end of the motor shaft, each bearing designed for both radial and axial loading. One of the bearings had become noisy. The bearing was found to have adequate grease.

This is the first time motor bearing replacement has been necessary on any of the three secondary sodium pumps. The No. I secondary pump has accumulated 19,332 hours of operation, No. 2, 19,257 hours and No. 3, 25,078 hours.

Past repairs to the secondary pumps have been limited to the following items.

Year $\quad$ Pump

$1962 \quad$ No. 2

1964 No. 1

1965 No. 3

$1966 \quad$ No. 1
Item

C. No. 1 Steam Generator Tube-To-Tube Sheet Weld Repairs

Welding of the 1200 water manifold tube-to-tube sheet joints was completed in May. Earlier information on this weld repair program is contained in Report Nos. $6,7,8$ and 9 . The joints were bubble tested by flooding the tubes and face of the tube sheet with water. The shell side of the steam generator was pressurized with 35 psig nitrogen and five leaking welds were revealed. The tubes were rewelded and a second test showed them to be leak tight.

The water has been blown from the tubes and manifolds. Temporary covers have been installed on the manifolds and the tubes and manifolds are presently being purged with nitrogen to minimize corrosion while a study is under way to determine the feasibility of stress relieving the water manifold. 


\section{Preparations for Sodium Drain Operation}

See Pages 20-22 of Report No. 9 for background information on the sodium drain operation. Preparations necessary to permit draining the sodium were continued during May and were about 75 percent complete at the end of the month.

The shield plugs have been removed from the two lower guide tube access ports in the reactor rotating plug. The syphon pipe for draining the sodium will be installed in one of these ports (see Section IV B of Report No. 9). The pipe and its removal container are ready for installation. The upper photograph on Page 30 shows one of the lower guide tube shield plugs being removed through the adaptor and valve into the plug container. A viewing window was installed on one of the adaptors and the reactor sodium level was lowered several feet to permit inspection of the sodium surface. The surface is clear and bright.

The reactor rotating plug Klozure seal backup gasket has been installed as shown in the lower photograph on Page 30 . A leak test revealed leaks around the ball bearing inspection ports and these are being repaired. A connection has been made to the primary inert gas supply system so that the gas pressure in the space between the klozure seal and the backup gasket will be the same as the pressure inside the Klozure seal.

The temporary drain line connection has been installed from alongside the reactor to below the operating floor. A flowmeter has been installed in this section of pipe and taps and a throttling valve are being provided to permit connection of a sodium sampling container.

The below-floor tie-in connections for the drain line were made under adverse welding conditions including a high ambient temperature and an awkward, crowded work area. The 3-inch stainless steel butt welds were made by dry-ice freezing of the sodium, cutting the lines, scooping out the solid sodium, preparation of the pipe ends, installing consumable inserts, making the fusion pass, adding the filler passes and $x$-raying the completed welds. Several x-rays revealed porosity in the fusion pass requiring cutting and rewelding. This is thought to be due to welder inexperience rather than to sodium penetration into the metal grain boundaries or to the presence of sodium vapors.

The sodium storage room is ready to be inerted with nitrogen except for the addition of a viewing window in the door and replacement of the existing blower motor with a larger sized motor. 


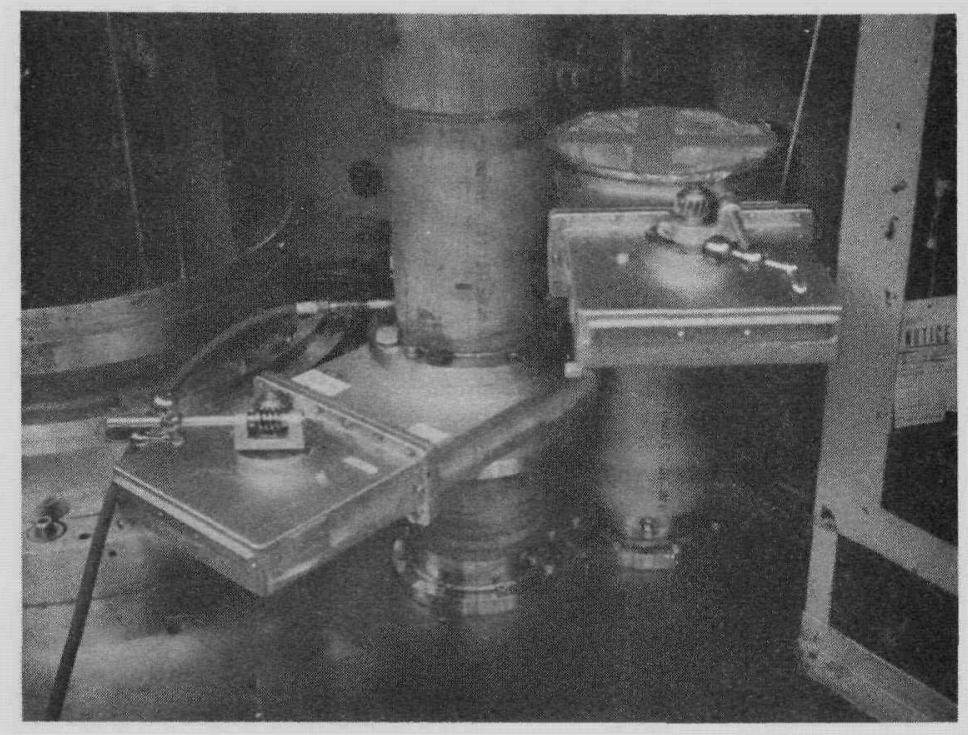

ADAPTORS AND VALVES

INSTALLED FOR ACCESS TO

REACTOR CORE THROUGH

THE PLUG PENETRATIONS.

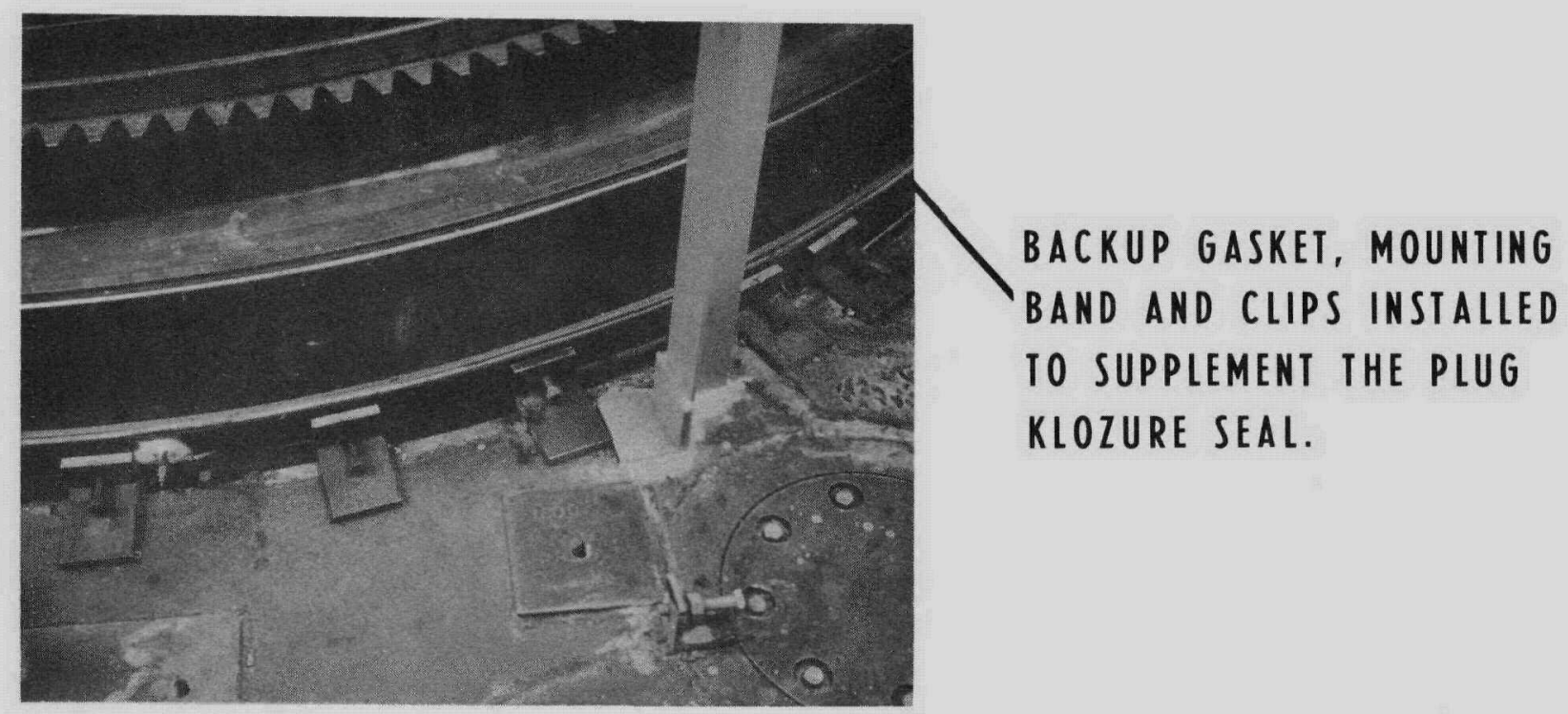

ADDITIONS TO REACTOR ROTATING PLUG 